\title{
UCIECZKI Z TWIERDZY WISŁOUJŚCIE W I POŁOWIE XIX WIEKU
}

Streszczenie. Pod koniec XVIII wieku twierdza Wisłoujście trafiła pod panowanie Prus stając się ośrodkiem odosobnienia głównie dla Polaków, na przykład powstańców listopadowych, a także innych narodowości. W Twierdzy znajdowali się zarówno więźniowie polityczni, jak i kryminalni. Na podstawie listów gończych, zamieszczonych w czasopiśmie urzędowym rejencji gdańskiej (Amtsblatt der Königlichen Regierung zu Danzig) zaprezentowano ucieczki z Twierdzy w I połowie XIX wieku, których dopuszczali się kryminalni osadzeni, tzw. Baugefangene, jak również dezercje żołnierzy z jednostek wojskowych stacjonujących na twierdzy Wisłoujście i w jej okolicach.

Słowa kluczowe: ucieczki, dezercje, twierdza Wisłoujście, listy gończe, więźniowie.

U nikalny zabytek sztuki fortyfikacyjnej, jakim niewątpliwie jest położona na północ od Gdańska, twierdza Wisłoujście, doczekał się wielu opracowań. Najczęściej poruszanym zagadnieniem jest kwestia przemian architektonicznych obiektu. Szczególny nacisk w tych opracowaniach kładzie się z reguły na okres XVII-XVIII w., kiedy to Twierdza osiągnęła apogeum swojego rozwoju¹.

Na przestrzeni wieków obiekt pełnił wielorakie funkcje. Poza podstawową funkcją obronną, były to kwestie związane z administracją oraz reprezentowaniem miasta Gdańska, o czym świadczy fakt, iż Twierdza była obowiązkowym punktem wizyt dostojników odwiedzających gród nad Motławą ${ }^{2}$.

Zachodzące w XIX w. ogromne przemiany w sferze militarnej, a jednocześnie zmiany topografii ujścia Wisły spowodowały, że twierdza Wisłoujście

${ }^{1}$ G. Bukal, Fortyfikacje Gdańska i ujścia Wisły 1454-1793, Sopot 2012; idem, Fortyfikacje Gdańska 1454-1793, [w:] Fortyfikacje Gdańska, red. G. Bukala, Gdańsk 2009, s. 24-57.

${ }^{2}$ E. Kizik, Odwiedziny twierdzy Wisłoujście w XVII i XVIII w., [w:] Fortyfikacje Gdańska..., s. 141-149. 
zaczęła tracić swoje dotychczasowe znaczenie. Ostatni raz obiekt odegrał istotną rolę w czasie wojen napoleońskich, aby następnie stać się więzieniem. W literaturze przedmiotu wskazuje się dość nieprecyzyjnie, iż Twierdza pełniła funkcję więzienia politycznego, bądź to od 1815 r., bądź to od lat 20. XIX w. ${ }^{3} \mathrm{Z}$ pewnością już po II rozbiorze Polski, kiedy Gdańsk, a wraz z nim twierdza Wisłoujście, dostały się pod panowanie pruskie, utworzono tam więzienie ${ }^{4}$. Także w czasach okupacji Twierdzy przez wojska francuskie, obiekt wykorzystywano w tym celu5. Począwszy od lat 20. XIX w., Twierdzę zaczęto wykorzystywać jako miejsce odosobnienia głównie dla polskich więźniów politycznych. Jeszcze po I wojnie wojnie światowej przebywali tu więzieni przez władze pruskie Polacy ${ }^{6}$. Poza tym więziono tam również inne grupy społeczne, co ukazuje poniższa tabela (Tabela 1).

\section{Tabela 1}

Więźniowie przebywający w twierdzy Wisłoujście w XIX w.

\begin{tabular}{|c|c|c|}
\hline Rok/lata & Przyczyna uwięzienia & Więźniowie \\
\hline 1822 & $\begin{array}{l}\text { Demonstracja robotników zbożowych } \\
\text { w Gdańsku związana z obniżką płac }\end{array}$ & Około 20 robotników \\
\hline $1822-1824$ & $\begin{array}{l}\text { Założenie w Berlinie przez polskich stu- } \\
\text { dentów tajnego stowarzyszenia „Polo- } \\
\text { nia”, a także działalność w innych taj- } \\
\text { nych organizacjach }\end{array}$ & $\begin{array}{l}\text { Karol Marcinkowski, Franciszek Ko- } \\
\text { szutski, Gustaw Potworowski, Józef } \\
\text { i Franciszek Biegańscy, Adam Kon- } \\
\text { stanty Loga, Leon Śmitkowski, Erazm } \\
\text { Stablewski, Tadeusz Pągowski, Teles- } \\
\text { for Kurantowski, Dominik Sczaniecki, } \\
\text { Alojzy Zaborowski, Roman Osten i Jó- } \\
\text { zef Stefański }\end{array}$ \\
\hline $1831-1832$ & $\begin{array}{l}\text { Udział w powstaniu listopadowym } \\
\text { - odmowa złożenia przysięgi dotyczą- } \\
\text { cej zakazu ponownego przedarcia się } \\
\text { na tereny objęte powstaniem i pomocy } \\
\text { walczącym }\end{array}$ & $\begin{array}{l}21 \text { oficerów z karpusów Giełuda i Roh- } \\
\text { landa (w tym gen. Józef Szymanowski) }\end{array}$ \\
\hline
\end{tabular}

${ }_{3}^{3}$ M. Porowski, Dzieje więziennictwa polskiego w piśmiennictwie i dokumentach, Warszawa 2016, s. 37, 468.

${ }^{4}$ A.F. Violet, Neringia oder Geschichte der Danziger Nehrung, Gdańsk 1864, s. 81-82.

5 E. Schaumann, Die Danziger Presse im 19. Jahrhundert bis zur Gründung der "Danziger Zeitung”, „Zeitschrift des Westpreußischen Gesichtsvereins” 1935, Bd. 72, s. 16.

6 Świadczy o tym chociażby tablica pamiątkowa znajdująca się w Kwidzynie, poświęcona pierwszemu wybieralnemu burmistrzowi Świecia n/Wisłą Stanisławowi Kostce (1874-1938), na której zapisano, iż tenże za swoją działalność niepodległościową więziony był przez władze pruskie w twierdzy Wisłoujście w 1919 r. - w tym miejscu pragnę podziękować magistrowi Marcinowi Szumnemu za wskazanie mi na powyższe źródło. 


\begin{tabular}{|c|c|c|}
\hline Rok/lata & Przyczyna uwięzienia & Więźniowie \\
\hline 1843 & $\begin{array}{l}\text { Kwietniowa rewolta robotników gdań- } \\
\text { skich }\end{array}$ & $\begin{array}{l}48 \text { tragarzy zboża (w tym także współ- } \\
\text { twórca Związku Plebejuszy - Walenty } \\
\text { Stefański) }\end{array}$ \\
\hline 1848 & $\begin{array}{l}\text { Ucieczka z Kongresówki celem uniknię- } \\
\text { cia poboru do carskiej armii tłumiącej } \\
\text { powstania narodowościowe w okresie } \\
\text { Wiosny Ludów }\end{array}$ & 74 Polaków z Królestwa Polskiego \\
\hline $1851-1854$ & $\begin{array}{l}\text { Opór przeciwko władzy, uszkodzenie } \\
\text { ciała, zabójstwo }\end{array}$ & $\begin{array}{l}\text { Czerkiesi - Bakmirza Nafimov, Nabi } \\
\text { Mel'bahov, Šoloh Gabzachov, Grandu- } \\
\text { ka Hapuf, Musa Erkanov }\end{array}$ \\
\hline $1863-1865$ & $\begin{array}{l}\text { Udział w powstaniu styczniowym, gło- } \\
\text { szenie na łamach prasy postępowych } \\
\text { haseł społecznych i ekonomicznych }\end{array}$ & $\begin{array}{l}\text { M.in.: Ignacy Danielewski, Wal. Ste- } \\
\text { fański, Józef Chociszewski, Symforian } \\
\text { Tomicki, Leon Martwell, Teodor Jac- } \\
\text { kowski, Edward Kalkstein, Julian Mit- } \\
\text { telstaedt, Serafin Ulatowski }\end{array}$ \\
\hline 1898 & „Obraza majestatu cesarza niemieckiego” & Johannes Trojan \\
\hline
\end{tabular}

Źr ó dła: L. Mokrzecki, Twierdza Wisłoujście, Gdańsk 1978, s. 19-20; G. Sander, Tscherkessen in Weichselmünde, „Mittheilungen des Westpreußischen Gesichtsvereins”, 1902, Jg. 1, nr 3, s. 53-57; I. Fabiani-Madeyska, Odwiedziny Gdańska w XIX wieku, Gdańsk 1957, s. 85-107; Pomorze Gdańskie 1807-1850, oprac. A. Bukowski, Wrocław 1958, s. 191, 196-197.

Wśród pozostałych grup społecznych, szczególnie interesujący jest przypadek przebywających na początku lat 50. XIX w. w Wisłoujściu czerkieskich wojowników. Pochodzący ze wschodnich wybrzeży Morza Czarnego koczownicy, słynęli z ogromnej odwagi oraz opanowanej do perfekcji sztuki wojny. Część tamtejszej szlachty w czasie Wiosny Ludów służyła w oddziałach rosyjskich jako najemnicy, wchodząc w skład Kaukaskiego Konnego Dywizjonu Górskiego. Po zakończeniu działań na Węgrzech, Dywizjon Kaukaski stacjonował na terenach Królestwa Polskiego, gdzie doszło do konfliktu między niepokornymi najemnikami, a dowództwem ${ }^{7}$. Konflikt spowodował ucieczkę Czerkiesów do Prus, gdzie ze względu na egzotyczny ubiór oraz niecodzienne zachowanie zwrócili oni na siebie uwagę miejscowej społeczności. Władze pruskie nie zamierzały pozwolić dezerterom osiąść na terytorium Prus, dążąc do odesłania ich na mocy umowy kartelowej z 1844 r. z powrotem do Rosji. Kiedy miejscowy landrat poprosił najemników o złożenie broni, rozegrała się regularna walka, pomiędzy dziesięcioma Czerkiesami,

${ }^{7}$ T. Krzemiński, Od stoków Kaukazu po Weichselmünde - niedole czerkieskich najemników w Prusach około połowy XIX wieku, „Czasy Nowożytne” 2015, t. 28, s. 148. 
a rezydującym w Inowrocławiu szwadronem 3. pułku dragonów. Pomimo znaczącej przewagi Prusaków, Czerkiesom udało się podjąć ucieczkę, a następnie zabarykadować w niewielkim budynku należącym do folwarku Kruśliwiec ${ }^{8}$. Ostatecznie po ciężkich bojach, w których zginęło dwóch pruskich żołnierzy i czterech dezerterów, Czerkiesi zostali pojmani, a następie osądzeni. W uznaniu za ich męstwo, które zjednało im sympatię lokalnej ludności, skazano ich na względnie niskie kary (dwa lata twierdzy), które odbyć mieli w położonej na północ od Gdańska twierdzy Wisłoujście ${ }^{9}$. Ostatecznie zasądzony wyrok odbywało pięciu Czerkiesów, z których jeden - Nabi Mel'bahov - niedługo po przybyciu do Wisłoujścia zmarł na gorączkę gastryczno-nerwowq ${ }^{10}$. Pozostali osadzeni po odbyciu kary znaleźli zatrudnienie w stajniach Królewskich w Berlinie. Jedynie Granduka Hapuf nie dotrwał końca wyroku i w międzyczasie przy pomocy kapitana brytyjskiego statku opuścił Gdańsk ${ }^{11}$.

Należy zaznaczyć, iż pobyt w twierdzy Wisłoujście w przypadku więźniów stanu był względnie łagodną formą kary. Świadczą o tym rozliczne relacje, które pozostawili po sobie więźniowie odbywający zasądzony wyrok w murach nadmorskiej fortecy. Między innymi całe grono powstańców listopadowych. Opuszczając mury Twierdzy, major Karbowski zwracał się do komendanta w Wisłoujściu:

Tścigodny Pułkowniku! Rozpraszaionc się w różne strony z Weychselmindy, żegnam ze łzami Ciebie, lecz w każdey koleii Losu uwielbieniem wspominać bendę rzadkie przymioty Duszy i serca. Boże! przedłużay lata rzadkich cnót Menża dla dobra ludzkości cierpioncey i dla roszkoszy tych, którym zamienia wolność w powrót Rodzinom Oyców, Menżów i Braci [...] ${ }^{12}$.

Więziony w twierdzy Wisłoujście ks. Symforian Tomicki w swoich Sonetach Wisłuścia z podziwem pisał:

Oto twierdza Wisłouścia! - serce drgnęło w łonie, Lecz spokój wkrótce wrócił znów na chmurne lica, Bo urocza to twierdza całkiem mnie zachwyca, Co dumnie się spoziera i na morskie tonie ${ }^{13}$.

Jeden z gości odwiedzających trzymanego na Twierdzy, mniej więcej w tym samym czasie, autora Wisły Ignacego Danielewskiego wspominał natomiast

8 Ibidem, s. 152.

${ }^{9}$ Ibidem, s. 158.

10 Ibidem, s. 159.

11 Ibidem, s. 160; G. Sander, Tscherkessen in Weichselmünde, „Mittheilungen des Westpreußischen Gesichtsvereins" 1902, Jg. 1, nr 3, s. 56-57.

12 Cit. I. Fabiani-Madeyska, Odwiedziny Gdańska w XIX wieku, Gdańsk 1957, s. 86.

${ }^{13}$ X.S. Tomicki, Kwiaty Więzienia, Gdańsk 1866, s. 67. 
na łamach prasy, iż tenże trzymany jest ciagle pod ryglem i zamkiem, a za mieszkanie służy mu mała ciupa z jednym oknem ${ }^{14}$.

Na przepływającym obok twierdzy Wisłoujście w latach 50. XIX w. Ludwigu Passarge zastany widok zrobił, jak się wydaje, ponure wrażenie. Autor szkiców z podróży po Delcie Wisły zapisał bowiem:

Nasz kuter cumuje teraz przy prawym brzegu, przy twierdzy Wisłoujście, gdzie wysadzamy kontyngent gości kąpieliska. W jednym z zakratowanych okien pojawia się na moment blada twarz; być może jest to jeden z trzymanych w niej więźniów politycznych. Omińmy to miejsce! Omińmy! ${ }^{15}$.

Owa blada twarz zauważona przez Passarge, nie musiała jednak wcale należeć do więźnia politycznego. Poza tą kategorią aresztantów w Twierdzy swoje wyroki odsiadywali bowiem również więźniowie kryminalni, określani powszechnie mianem Baugefangene. Jeden z anonimowych pensjonariuszy twierdzy Wisłoujście pisał o tej kategorii skazańców w sposób następujący:

Oprócz więźniów stanu była jeszcze inna kategorya skazańców w Wisłoujściu, tak zwani Baugefangene. Jeden z naszych podoficerów nazwał ich bogufani, że niby w Bogu ufają, a myśmy ich zwali kajdaniarzami, bo zawsze chodzili w kajdanach. Byli to przestępcy wojskowi i z floty, którzy się dopuścili morderstwa, dlatego też ponosili długoletnie kary, zwykle po 20 lat [...]. Chodzili oni co dzień na robotę pod wojskową strażą, a w celach trudnili się wyrabianiem szczotek. Głównym celem ich zabiegów, niejako marzeniem było uzyskanie prozaicznéj wódki. Usilne, wytrwałe starania wieńczył czasem pomyślny skutek. Istotnie trzeba było czynić nieraz nadludzkie wysilenia, aby przyjść w posiadanie spirytusu, zwłaszcza, że nie wolno im było mieć przy sobie ani grosza pieniędzy. Sprzedawali taniéj szczotki, aby dostać trochę mamony, a gdy tę mieli, znalazła się i wódka. Dopomagali im żołnierze i mieszkańcy Wisłoujścia, litując się nad losem biednych kajdaniarzy ${ }^{16}$.

Tak więc los owych Baugefangene znacznie różnił się od tego, jakiego doświadczali skazańcy polityczni w tym między innymi autor obszernej relacji z pobytu w Wisłoujściu - Johannes Trojan ${ }^{17}$. Dlatego też, to właśnie

14 J. Kałdowski, Ignacy Danilewski autor „Wisły” 1829-1907, Chełmno 1986, s. 10.

${ }^{15}$ L. Passarge, Z Wiślanej Delty. Tczew, Gdańsk, Żuławy, Malbork. Szkice z podróży 1856, tłum. W. Sawicki, Gdańsk 2016, s. 165.

${ }^{16}$ Opowiadania więźnia stanu, cz. 3. W Wisłoujściu, „Staszyc. Tygodnik obrazkowy dla oświaty i rozrywki, oraz mający na celu zachętę do zamiłowania oszczędności i pracy" 1889, nr 17, s. 135.

${ }_{17}$ J. Trojan, Mój ojciec, kupiec. Opowieści i wspomnienia z dziewiętnastowiecznego Gdańska, tłum. J. Mosakowski, Gdańsk 2017, s. 107-130. 
więźniowie kryminalni będą tą kategorią osadzonych, która podejmować będzie próby ucieczki z Twierdzy.

Materiałem, który pozwala na analizę zagadnienia związanego z ucieczkami z twierdzy Wisłoujście są listy gończe zamieszczone na łamach tygodnika urzędowego rejencji gdańskiej - „Amtsblatt der Königlichen Regierung zu Danzig". Czasopismo to zaczęło ukazywać się od 1816 r. i było wydawane nieprzerwanie aż po 1920 r. Znaczna część czasopisma została zdigitalizowana i znajduje się w zasobach Elbląskiej Biblioteki Cyfrowej. Niemal kompletne zbiory czasopisma znajdują się również w bibliotekach Uniwersyteckich w Gdańsku i Toruniu oraz Gdańskiej Bibliotece Polskiej Akademi Nauk.

Badaniem objęto czasopismo za lata 1816-1848. W wyniku kwerendy pozyskano łącznie około 1500 listów gończych, które znajdowały się bądź to w samym czasopiśmie, bądź też dodatkach do czasopisma (Öffentlicher Anzeiger, Extra Beilage). Wśród przebadanych listów gończych tylko sześć dotyczyło ucieczek z twierdzy Wisłoujście, natomiast jeden dotyczył żołnierza służącego wcześniej w obiekcie. Dodatkowo przebadano także bydgoskie czasopismo urzędowe za lata 1815-1816, gdzie udało się odnaleźć jedynie informację o zbiegłym najprawdopodobniej w 1815 r. z twierdzy Wisłoujście Martinie Rosińskim. Informacja z 12 lutego 1816 r. wskazywała tylko, iż Rosińskiego udało się znaleźć i schwytać w Królewcu, gdzie przebywał pod fałszywym nazwiskiem Braun ${ }^{18}$. Być może analogiczne informacje odnaleźć można również w listach gończych zamieszczanych w pozostałych dziennikach urzędowych Królestwa Prus ${ }^{19}$, bądź lokalnej prasie Gdańskiej tego $\mathrm{okresu}^{20}$, jednak analiza tego typu wydawnictw wymaga dalszych wieloletnich i żmudnych kwerend.

Poza więźniami, część listów gończych dotyczy również dezerterów zbiegłych z rezydujących na twierdzy Wisłoujście jednostek wojskowych. I tak na przykład 25 maja 1822 r. na łamach gdańskiej gazety ukazał się list gończy wydany za niejakim Friedrichem Krügerem, będącym podoficerem w jednym z oddziałów wchodzących w skład I batalionu Pułku Grenadie-

${ }_{18}$ Oeffentlicher Anzeiger. Beilage des Amts=Blatts Nro. 7. der Königl. Bromb. Regierung, 1816, s. 35.

${ }^{19}$ Szerzej na temat wydawanych w Królestwie Prus dziennikach urzędowych - v.: P. Canick, Verwaltung und Öffentlichkeit in Preußen. Kommunikation durch Publikation und Beteiligungsverfahren im Recht der Reformzeit, Frankfurt a. Main 2006, s. 70 i nn.

${ }^{20}$ Na temat gdańskich czasopism w początkach XIX w. - v.: M. Chojnacka, Prasa Gdańska w pierwszej połowie XIX wieku, [w:] Prasa Gdańska na przestrzeni dziejów, red. M. Andrzejewski, Gdańsk 1999, s. 56-62; Die Zeitschriften des Deutschen Sprachengebietes von den Anfängen bis 1830, bearb. von J. Kirchner, Stuttgart 1969. 
rów im. Króla Fryderyka I [4. Wschodniopruski] nr $5^{21}$. Jak wskazano w liście gończym Krüger zbiegł z Gdańska zaraz po otrzymaniu żołdu za służbę na Twierdzy, który to żołd wynosił ponad 22 talary $^{22}$. W rysopisie podano, iż dezerter urodził się w Królestwie Polskim, miał 28 lat, był ewangelikiem, a ponadto posługiwał się językami niemieckim i polskim. Posiadał blond włosy i niebieskie oczy, był szczupły i dość niski (ok. $167 \mathrm{~cm}$ ). Dodatkowo odnotowano, iż Krüger posiada przy sobie świadectwo wcześniej odbytej służby wojskowej ${ }^{23}$. Zbiega ostatecznie udało się schwytać, o czym zawiadamia umieszczona na łamach gdańskiego czasopisma informacja z dnia 12 czerwca $1822 \mathrm{r}^{24}$ Innym ciekawym przypadkiem w którym podejrzewano dezercje, jest sprawa niejakiego Jakoba Warrasa urodzonego w Pucku Fizyliera z Pułku Grenadierów im. Króla Fryderyka I [4. Wschodniopruski] nr 5, który zaginął w nocy z 16 na 17 listopada 1822 r. W świetle zeznań podpułkownika (Oberst = Lieutenant) Jochemsa, dezercja Warrasa była wątpliwa, bowiem jak zeznał światek ten zawsze dobrze się prowadził (immer gut geführt). Z tego też względu podporucznik podejrzewał najgorsze. W tym przypadku świadek miał racje, bowiem w kwietniu następnego roku, ciało rzekomego dezertera odnaleziono w zewnętrznej fosie twierdzy Wisłoujście. Denat miał 21 lat, mierzył 5 stóp i 3 cale $^{25}$.

Innym dezerterem który opuścił mury Twierdzy, był Carl Tietz. Ten, podobnie jak jego poprzednicy, również służył w Pułku Grenadierów im. Króla Fryderyka I. Urodzony w Chełmnie dwudziestoletni muszkieter zniknął w nocy z 13 na 14 marca $1823 \mathrm{r}$. Za dezercją przemawiał fakt, iż Tietz opuszczając oddział zabrał ze sobą przedmioty należące do swoich towarzyszy broni $^{26}$. I tym razem zbiega udało się odnaleźć, o czym zawiadamia nota z 17 czerwca 1823 r. opublikowana na łamach gdańskiego czasopisma ${ }^{27}$.

Niewątpliwie najciekawszym z odnalezionych listów gończych jest ten, który dotyczy ucieczki mającej miejsce 18 lutego 1828 r. W tym przypadku bowiem, możemy domyślać się w jaki sposób osadzonemu w twierdzy Wisłoujście więźniowi Johannowi Palkowskiemu, określanemu mianem Baugefangene, udało się zbiec. Palkowskiego oskarżono o rozbój na drodze

${ }^{21}$ Na temat stacjonujących w tym czasie w Gdańsku garnizonów - vide: H. Sommer, Pruskie garnizony wojskowe w Poznańskiem, Prusach Zachodnich i na Górnym Śląsku, Oświęcim 2011, s. 38-40; E. Raabe, Die Festung Danzig und ihre Garnison, Hamburg 1996, s. 236.

${ }^{22}$ Amts=Blatt der Königlichen Regierung zu Danzig [dalej: Amtsblatt zu Danzig], 1822, s. 344.

${ }^{23}$ Ibidem, s. 344.

${ }^{24}$ Amtsblatt zu Danzig, 1822, s. 376.

25 Ibidem, s. 701; Amtsblatt zu Danzig, 1823, s. 251.

${ }^{26}$ Amtsblatt zu Danzig, 1823, s. 210-211.

27 Ibidem, s. 397. 
i skazano na dożywotnie roboty w Twierdzy. W czasie odsiadki ten trzydziestoletni ospowaty mężczyzna, chętnie chwalił się dużą ilością pieniędzy, którą najpewniej pozyskał w wyniku rozboju i którą rzekomo ukrył w swej ojczyźnie. Opowieść ta skłoniła najprawdopodobniej pilnującego Palkowskiego muszkietera Lucasa Topolskiego do pomocy w ucieczce oskarżonemu. Świadczy o tym fakt, iż w rysopisie Topolskiego podano, iż ten jest bardzo naiwny (sehr einfältig) ${ }^{28}$. Obaj zbiedzy nie cieszyli się wolnością zbyt długo, bowiem już 2 marca tego samego roku, zawiadamiano o ponownym schwytaniu uciekinierów ${ }^{29}$.

W 1832 r. miała z kolei miejsce ucieczka niejakiego Casimira Lawdanskiego. Zbiegły 12 lipca z twierdzy Wisłoujście były porucznik Krakusów, zapewne brał udział $\mathrm{w}$ powstaniu listopadowym, a następnie trafił na teren Prus $^{30}$. Z powodu umyślnego zabójstwa wyrokiem w pierwszej instancji skazano go na 15 lat pobytu w Twierdzy. Lawdanski urodził się na Żmudzi, w chwili ucieczki miał 26 lat, był bardzo wysoki (ok. $190 \mathrm{~cm}$.) i posługiwał się wyłącznie językiem polskim, znając jedynie kilka słów w języku niemieckim. Poza niezdrową cerą twarzy, zbiegły posiadał na kolanie bliznę po ranie ciętej. Ubrany był w granatowy sukienny frak, na szyi nosił czarną bindę, posiadał szare płócienne spodnie i krótkie buty ${ }^{31}$. W tym przypadku brak jakiejkolwiek informacji o schwytaniu uciekiniera.

Trzy lata później miała miejsce kolejna ucieczka. Tym razem 31 maja 1835 r. z - jak określono to w źródle - Fortu Wisłoujście zbiegło dwóch więźniów kryminalnych (Baugefangenen) Johann Martin Krause oraz Christian Bernstein. Niestety nie podano za co oskarżeni odsiadywali zasądzony wyrok. W rysopisie Martina Krause zaznaczono, iż ten urodził się na terenie Prus Wschodnich, był ewangelikiem, miał 37 lat i mierzył ok. $167 \mathrm{~cm}$. Posługiwał się językiem polskim, niemieckim oraz litewskim. Jako cechy szczególne odnotowano m.in.: bliznę powyżej łokcia, ranę na prawym przedramieniu powstałą prawdopodobnie $\mathrm{w}$ wyniku postrzału, przekłute ucho, dwie małe brodawki na lewym policzku oraz bliznę po ospie. Ponadto, na prawym przedramieniu Krause posiadał wytatuowaną w kolorze czerwonym kotwicę. Bernstein z kolei urodził się w Grudziądzu, miał 27 lat, był podobnego jak Krause wzrostu, mówił po niemiecku i trochę po polsku. Co

${ }^{28}$ Amtsblatt zu Danzig, 1828, s. 86-87.

${ }^{29}$ Ibidem, s. 94.

${ }^{30}$ Więcej na temat powstańców listopadowych internowanych na teren Gdańska v.: S. Mikosz, Powstańcy polscy z 1831 roku internowani w twierdzy gdańskiej i na Biskupiej Górce, „Rocznik Gdański” 1961, t. 21, s. 39-50; idem, Uczestnicy powstania listopadowego internowani na terenie Pomorza Gdańskiego w latach 1831-1833, „Rocznik Gdański” 1963, t. 22, s. 165-167.

${ }^{31}$ Amtsblatt zu Danzig, 1832, s. 228; Oeffentlicher Anzeiger zu Nro 30. Amtsblatt der Königl. Regierung zu Bromberg, 1832, s. 570-571. 
ciekawe w przypadku obu zbiegów odnotowano, iż nosili koszule z inicjałami B.G., które z pewnością stanowiły abrewiacje słowa Baugefangene ${ }^{32}$. Obu zbiegów schwytano ponownie o czym powiadomiono czytelników obwieszczeniem z dnia 19 czerwca $1835 \mathrm{r}^{33}$

Ostatni odnotowany w źródle list gończy, dotyczy ucieczki dwóch więźniów kryminalnych, zbiegłych 7 listopada 1838 r. z miejsca pracy w Wisłoujściu (Arbeitsplatze bei Weichselmünde). Uciekinierami byli Heinrich Andreas Hoffmann oraz Gottlieb Eduard Pcherwaß. I tym razem nie podano przyczyny uwięzienia obu skazańców. Hoffman był 38 letnim katolikiem urodzonym w okolicach Kwidzyna, o względnie niskim wzroście wynoszącym powyżej $162 \mathrm{~cm}$, posługującym się językim polskim i niemieckim. Co interesujące, odnotowano, iż nie posiadał w górnej szczęce przednich zębów oraz że na jego środkowym palcu u lewej dłoni znajdował się uszkodzony paznokieć. Prawdopodobnie posiadał on również ranę w okolicach kostki, być może spowodowaną przytwierdzonym do nogi skazańca łańcuchem. Podobnie jak Hoffman, również Pcherwaß posiadał podobną ranę, a ponadto na jego lewym policzku w okolicach kącika ust znajdowała się blizna. Pcherwaß był nieznacznie niższy od Hoffmana, miał 30 lat, był ewangelikiem urodzonym w Iławie Pruskiej i mówił wyłącznie po niemiecku ${ }^{34}$. W przypadku obu uciekinierów brak jakichkolwiek informacji o ich schwytaniu.

Analiza listów gończych, dotyczących ucieczek z twierdzy Wisłoujście, pozwala na sformułowanie kilku istotnych wniosków, nie eksponowanych dotychczas szerzej w literaturze przedmiotu. Po pierwsze pozwala stwierdzić jednoznacznie, iż więźniowie stanu, czy też więźniowie polityczni nie byli jedyną kategorią osób przetrzymywanych na terenie obiektu. Przynajmniej do końca lat 30. XIX w. (a z pewnością i później) znajdowali się tam bowiem również więźniowie kryminalni określani mianem Baugefangene, którzy nosili określony strój identyfikujący ich jako grupę osadzonych. Po drugie, przy całej obfitości materiału źródłowego, ucieczki z twierdzy Wisłoujście pojawiają się bardzo rzadko, co może wskazywać na fakt małej ilości więźniów kryminalnych w obiekcie, bądź na to, iż położenie Twierdzy i jej obsada skutecznie utrudniały skazańcom podjęcie efektywnej próby ucieczki - argument ten zdaje się potwierdzać mała ilość indywidualnych tego typu prób. Po trzecie, daje się zauważyć, że większość zbiegów bardzo szybko chwytano, tak iż z reguły wracali do miejsca przeznaczenia w okresie nieprzekraczającym kilku miesięcy. Wypada także zauważyć, że poza ucieczkami więźniów, listy gończe zawierają również dezercje żołnierzy z jednostek

\footnotetext{
${ }^{32}$ Extra=Beilage zum No. 23 Amtsblatt der Königl. Regierung zu Danzig, 1835, s. 111-112.

33 Amtsblatt zu Danzig, 1835, s. 127.

${ }^{34}$ Ibidem, s. 209-210.
} 
wojskowych stacjonujących na twierdzy Wisłoujście, bądź w jej najbliższej okolicy. Ponieważ wszyscy odnotowani w listach gończych dezerterzy rekrutowali się z Pułku Grenadierów im. Króla Fryderyka I [4. Wschodniopruski] nr 5, należy przyjąć że to właśnie jeden z oddziałów tej formacji wojskowej stanowił garnizon rezydujący na obszarze Wisłoujścia w I poł. XIX w.

Należy zaznaczyć, iż odnalezione i przywołane tu listy gończe, nie zamykają tematu ucieczek z twierdzy Wisłoujście, a pogłębiona całościowa analiza prasy pruskiej i gdańskiej z pewnością pozwoliłaby na odnalezienie większej ilości źródeł dotyczących tego zagadnienia. Można zatem oczekiwać kolejnych prac, uzupełniających niniejszy skromny przyczynek do dziejów tego unikalnego w skali kraju obiektu, jakim niewątpliwie jest twierdza Wisłoujście.

\section{ANEKS \\ LISTY GOŃCZE DOTYCZĄCE UCIECZEK Z TWIERDZY WISŁOUJŚCIE W I POŁ. XIX W.}

\section{2}

Der Unterofficier Friedrich Krüger vom 5. (4. Ostpreu $\beta$.) Infanterie=Regimente, dessen Signalement unten beigefolgt, ist am 20. d. M. von Danzig, nachdem er hier das Traktament für das in Weichselmünde stehende Commando des ersten Bataillons gedachten Regiments mit 22 Rthlr. 5 Sgr empfangen, desertirt. [...]

Danzig, den 25. May 1822.

Signalement.

Beschreibung der Person: Familien=Name, Krüger. Vorname, Friedrich. Geburtsort, Wrotzlaweck im Königsreich Polen. Religion, evangelisch. Alter, 28 Jahre 8 Monate. Größe, 5 Fuß, 5 Zoll, 2 Strich. Haare, blond, etwas kraus. Stirn, platt. Augenbraunen, blond. Augen, blau. Nase, etwas groß. Mund, mittelmäßig. Bart, rasirt. Zähne, vollständig. Kinn, rund. Gesichtsbildung, oval. Gesichtsfarbe, gesund. Gestalt, schlank. Sprache, Polnisch und Deutsch. - Besondere Kennzeichen: an der rechten Seite unter dem Knie eine Narbe.

Bekleidung: Hosen, grau tuchene, mit rothen Kanten. Stiefeln, ordinaire, mit kurzem Schäften. Mütze, mit schwarzer Glanz=Leinwand überzogen. Hat sich vermuthlich einen Rock gekauft, dessen Farbe man nicht angeben kann.

Außerdem ist der zc. Krüger im Besitz eines Abschiedes von der ehemaligen Russisch=Deutschen Legion, dem jetztigen 30. Jnfanterie=Regimento (4. Rheinischen) 
von Jahre 1815 ausgefertigt, auf welchem er wahrscheinlich reiset. Das Datum und die Namens=Unterschrift desselben ist jedoch unbekannt.

Źródło: Amtsblatt zu Danzig, 1822, s. 344.

Der Füsilier Jakob Warras vom 5. Infanterie=Regiment, aus Putzig gebürtig, 20 Jahre 8 Monate alt, 8 Monate im Dienste, 5 Fu $\beta 3$ Zoll gro $\beta$, welcher vor seinem Eintritte in den Militair=Dienst sich in Oliva aufgehalten, war in Weichselmünde commandirt und wird seit der Nacht vom 16. bis 17. d. M. vermißt. Er hat mitgenommen eine bezogene Dienst=Mütze, eine blaue Tuchjacke, ein Paar neue graue Dienst=Hosen, einen Säbel nebst Koppel und Troddel.

Der Warras hat sich, nach dem Zeugnisse des Herrn Regiments=Commandeurs, Oberst=Lieutenants Jochems, immer gut geführt, so da $\beta$ seine Desertion bezweifelt und vielmehr besorgt wird, da $\beta$ er sonstig verunglückt sey. [...]

Źródło: Amtsblatt zu Danzig, 1822, s. 701.

\section{3}

Der Musketier Carl Tietz vom 5ten Infanterie=Regiment, aus Culm gebürtig, 20 Jahre 10 Monate alt, 5 Fuß 5 Zoll gro $\beta$, 1 Jahr 1 Monat im Dienste, welcher vor seinem Eintritte in das Militair sich in Reisenburg aufgehalten und zuletzt in Weichselmünde commandirt gewesen, wird seit der Nacht vom 13. zum 14. d. M. vermißt. Da er bei seiner Entweichung nicht allein mehrere von seinen Sachen, sondern auch von den seiner Cameraden mitgenommen hat, die unten verzeichnet sind, so läßt sich seine Desertion mit Wahrscheinlichkeit annehmen. [...]

\section{Verzeichni $\beta$ \\ der mitgenommenen Sachen.}

Ein Paar Schuhe und ein Hemde, beides noch nicht ausgetragen. Außerdem hat der Tietz die Dienst=Mütze und ein Paar neue Dienst=Hosen des Musketiers Franz, so wie eine neue Jacke eines Musketiers imgleichen eine wollene Decke nebst Ueberzug aus der Caserne entwendet und mitgenommen.

Danzig, den 19. März 1823.

Źródło: Amtsblatt zu Danzig, 1823, s. 210-211.

\section{8}

Der Baugefangene Johann Palkowski und der ihn bewachende Musketier Lucas Topolski, sind am 18. d. M. aus dem Fort Weichselmünde entwichen. Beide Personen sind in den beigefügten Signalements näher beschrieben. [...] Danzig, den 21. Februar 1828. 


\section{Person=Beschreibung}

A. des Baugefangenen Johann Palkowski, Sohn eines bereits verstorbenen Hirten zu Succemin bei Pr. Stargardt, katholischer Religion, früher Dragoner, und jetzt wegen Straßenraubes zu lebenswieriger Festungsarbeit verurtheilt. Alter, 30 Jahr. Größe, $5 \mathrm{Fu} \beta 5$ Zoll. Haare, zwischen blond und braun, kurz verschnitten. Stirn, flach. Nase, proportionirt. Augen, zwischen grau und braun. Mund, klein. Kinn, rund. Bart, braun, kurz und Zunehmen. Gesicht, kurz und breit. Gesichtsfarbe, gesund. Statur, stark und kräftig. Sprache, polnisch und auch ziemlich deutsch. Besondere Kennzeichen: Pockengruben.

Bekleidung: bei seiner Entweichung trug er die gewöhnlichen Kleider der Baugefangenen, nemlich Jacke und Hosen aus gelben und grauem Tuch zusammengesetzt, grau tuchene Mütze und Schuhe. Außerdem hatte er ein stark verniethetes Halseisen. Später soll er aber in einer Infanterie=Montirung gesehen worden seyn. Er prahlt gern mit vielem Gelde, welches er in seiner Heimath verwahrt hatte.

B. des Musketiers Lucas Topolski, des 4. Infanterie=Regiments, aus Kommorowo bei Strasburg gebürtig und katholischer Religion. Alter, 25 Jahr. Größe, 5 Fu $\beta 1$ Zoll. Haare und Bart, braun. Augen, grau. Stirn, Nase, Kinn und Gesicht, gewöhnlich. Gesichtsfarbe, gesund. Statur, mittelmäßig, Sprache, nur polnisch. Besondere Kennzeichen: sehr einfältig.

Bekleidung: vollständige Infanterie=Montirung nebst einem grau tuchenen Mantel, der einen eben solchen sehr hohen Kragen hatte und auf den Schultern mit weißem Leder besetzt war.

Außerdem war er mit Säbel und Patrontasche mit weißen Riemenzeuge und mit einem geladenen Gewehr versehen.

Źródło: Amtsblatt zu Danzig, 1828, s. 86-87.

\section{2}

Der wegen Todtschlags in erster Instanz zu einem funfzehnjährigen Festungs=Arrest verurtheilte polnische Flüchtling, der vormalige Krakusenlieutenant Casimir Lawdanski aus Burbiszk in Samogitien gebürtig, ist am 12. Juli c. aus der Festung Weichselmünde entwichen. [...]

Danzig, den 16. Juli 1832.

Signalement.

Name, Casimir Lawdanski polnischer Flüchtling. Stand, ehemals Krakusen=Lieutenant. Vaterland, Burbiszk in Samogitien. Letztere Aufenthaltsort, Veste Weichselmünde. Religion, katholisch. Alter, 26 Jahr 6 Monate. Größe, 6 Fuß 2 Zoll. Haare, dunkelblond und schwach gekräuselt. Gesichts, nichts besonderes. Zähne, weiß und vollständig. Bart, starken auf der Oberlippe und starken Backenbart. Gesichtsfarbe, 
nicht gesund. Statur, gut gewachsen und stark von Knochen. Sprache, polnisch, nur wenig deutsche Worte. Besondere Kennzeichen: eine Schnittnarbe am Kinn.

Bekleidet war derselbe mit einem blau tuchenen Leibrock, schwarzer steifer Halsbinde, weißer Weste, grau tuchnen Hosen und kurzen Stiefeln.

Źródło: Amtsblatt zu Danzig, 1832, s. 228.

\section{5}

Die nachstehend signalisirten Baugefangenen Johann Martin Krause und Christian Bernstein sind am 31. Mai c. aus dem Fort Weichselmünde entwichen. [...]

Danzig, den 2. Juni 1835.

Signalement des Krause.

Familienname, Krause. Vroname, Johann Martin. Geburtsort, Groß Friedrichsgraben. Religion, evangelisch. Alter, 37 Jahre. Größe, 5 Fuß 6 Zoll. Haare, schwarzbraun. Stirn, hoch. Augenbraunen, braun. Augen, blaugrün. Nase, etwas tiefliegend. Mund, lang. Bart, schwarzbraun. Zähne, nach der rechten Seite zu gewöhnlich, vollständig und weiß. Kinn, rund. Gesichtsbildung, oval. Gesichtsfarbe, gesund. Getalt, kräftig. Sprache, deutsch, litthauisch und polnisch. Besondere Kennzeichen, eine Narbe über dem Ellbogen, am rechten Unterarm angeblich eine Schußwunde. Das linke Ohr ist durchstochen, 2 kleine Warzen auf der linken Wange; in der Richtung der Nase, eine größere ein Zoll tiefer in der Richtung des Mundes und eine große Pockennarbe über dem rechten Auge, auf dem rechten Unterarm ein rothes Anker tätovirt, auf dem linken Augen einen grünen Fleck und an der linken Hand gerade auf den Adern des Zeigefingers eine Narbe.

Bekleidung: eine graue Jacke, ein Paar graue Hosen, eine Mütze, ein Hemde, welches mit 2 Stempeln, worin die Buchstaben B.G. vorhanden, versehen.

\section{Signalement des Bernstien.}

Familienname, Bernstein. Vorname, Christian. Geburtsort, Graudenz. Religion, evangelisch. Alter, 27 Jahr 6 Monat. Größe, 5 Fuß 5 1/2 Zoll. Haare, dunkelblond. Stirn, bedeckt. Augenbraunen, dunkelbraun. Augen, grau. Nase, länglich. Mund, gewöhnlich. Bart, rasirt. Zähne, gut. Kinn, spitz und etwas eingebogen. Gesichtsbildung, länglich. Gesichtsfarbe, blaß. Gestalt, mittel. Sprache, deutsch und etwas polnisch. Besondere Kennzeichen, keine.

Bekleidung: eine Mütze, ein blaues Ueberhemde, ein Hemde, welches mit 2 Stempeln, worin die Buchstaben B.G. vorhanden, versehen.

Źródło: Extra=Beilage zum No. 23 Amtsblatt der Königl. Regierung zu Danzig, 1835, s. 111-112. 


\section{8}

Die nachstechend signalisirten Baugefangenen Heinrich Andreas Hoffmann und Gottlieb Eduard Pcherwaß sind am 7. d. Mts. von dem Arbietsplatze bei Weichselmünde entwichen. [...]

Danzig, den 12. Juli 1838.

Signalement des Hoffmann.

Familienname: Hoffmann; Vorname: Heinrich Andreas; Geburtsort: Schwanenland bei Marienwerder; Aufenthaltsort: Kl. Gilve bei Riesenburg; Religion: katholisch; Alter: 38 Jahr; Größe: 5 Fuß 4 Zoll 3 Strich; Haare, schwarz; Stirn: frei; Augenbraunen: schwarz; Augen: graublau; Nase: platt und stark; Mund: gewöhnlich; Bart: schwach; Zähne: gesund; Kinn: rund; Gesichtsbildung: rund; Gesichtsfarbe: bleich; Gestalt: schlank; Sprache: polnisch und deutsch; besondere Kennzeichen: in der obern Reihe fehlt ein Vorderzahn und hat an dem dritten Finger der linken Hand einen Scharfnagel, und wahrscheinlich eine Verletzung an den Fußgelenken.

Bekleidung ist nicht zu ermitteln gewesen.

Signalement des Pcherwaß.

Familienname: Pcherwaß; Vorname: Gottlieb Eduard; Geburtsort: Pr. Eylau; Religion: evangelisch; Alter: 30 Jahr; Größe: 5 Fuß 3 Zoll; Haare: kraus und schwarzbraun; Stirn: frei; Augenbraunen: braun; Augen: klein und grau; Nase: breit; Mund: gewöhnlich; Bart: braun; Zähne: gut; Kinn: breit; Gesichtsbildung: oval; Gesichtsfarbe: gesund; Gestalt; mittel; Sprache: deutsch; besondere Kennzeichen: auf der linken Backe im Mundwinkel eine Narbe und wahrscheinlich eine Verletzung an den Fußgelenken.

Bekleidung ist nicht zu ermitteln gewesen.

Źró dło: Amtsblatt zu Danzig, 1838, s. 209-210.

\section{BIBLIOGRAFIA}

\section{Źródła}

Amtsblatt der Königlichen Brombergischen Regierung, 1815-1816.

Amtsblatt der Königlichen Regierung zu Danzig, 1816-1848.

Opowiadania więźnia stanu, cz. III. W Wisłoujściu, „Staszyc. Tygodnik obrazkowy dla oświaty i rozrywki, oraz mający na celu zachętę do zamiłowania oszczędności i pracy” 1889, nr 17, z. 27 kwietnia, s. 134-136.

Passarge L., Z Wiślanej Delty. Tczew, Gdańsk, Żuławy, Malbork. Szkice z podróży 1856, tłum. W. Sawicki, Gdańsk 2016. 
Pomorze Gdańskie 1807-1850. Wybór źródeł, oprac. A. Bukowski, Wrocław 1958.

Tomicki S., Kwiaty więzienia, Gdańsk 1866.

Trojan J., Mój ojciec, kupiec. Opowieści i wspomnienia z dziewiętnastowiecznego Gdańska, tłum. J. Mosakowski, Gdańsk 2017.

\section{Opracowania}

Bukal G., Fortyfikacje Gdańska i ujścia Wisły 1454-1793, Sopot 2012.

Bukal G., Fortyfikacje Gdańska 1454-1793, [w:] Fortyfikacje Gdańska, red. G. Bukala, Gdańsk 2009, s. 24-57.

Canick P., Verwaltung und Öffentlichkeit in Preußen. Kommunikation durch Publikation und Beteiligungsverfahren im Recht der Reformzeit, Frankfurt a. Main 2006.

Chojnacka M., Prasa Gdańska w pierwszej połowie XIX wieku, [w:] Prasa Gdańska na przestrzeni dziejów, red. M. Andrzejewski, Gdańsk 1999, s. 56-62.

Die Zeitschriften des Deutschen Sprachengebietes von den Anfängen bis 1830, red. von J. Kirchner, Stuttgart 1969.

Fabiani-Madeyska I., Odwiedziny Gdańska w XIX wieku, Gdańsk 1957.

Ignacy Danielewski autor „Wisły” 1829-1907, red. J. Kałdowski, Chełmno 1986.

Kizik E., Odwiedziny twierdzy Wisłoujście w XVII i XVIII w., [w:] Fortyfikacje Gdańska, red. G. Bukal, Gdańsk 2009, s. 141-149.

Krzemiński T., Od stoków Kaukazu po Weichselmünde - niedole czerkieskich najemników w Prusach około połowy XIX wieku, „Czasy Nowożytne” 2015, t. 28, s. 145-162.

Mikosz S., Powstańcy polscy z 1831 roku internowani w twierdzy gdańskiej i na Biskupiej Górce, „Rocznik Gdański” 1961, t. 21, s. 39-50.

Mikosz S., Uczestnicy powstania listopadowego internowani na terenie Pomorza Gdańskiego w latach 1831-1833, „Rocznik Gdański” 1963, t. 22, s. 165-167.

Mokrzecki L., Twierdza Wisłoujście, Gdańsk 1978.

Porowski M., Dzieje więziennictwa polskiego w piśmiennictwie i dokumentach, Warszawa 2016.

Raabe E., Die Festung Danzig und ihre Garnison, Hamburg 1996.

Sander G., Tscherkessen in Weichselmünde, „Mittheilungen des Westpreußischen Gesichtsvereins" 1902, R. 1, nr 3, s. 53-58.

Schaumann E., Die Danziger im 19. Jahrhundert bis zur Gründung der „Danziger Zeitung”, „Zeitschrift des Westpreußischen Gesichtsvereins" 1935, Bd. 72, s. 7-96.

Sommer H., Pruskie garnizony wojskowe w Poznańskiem, Prusach Zachodnich i na Górnym Ślasku, Oświęcim 2011.

Violet A.F., Neringia oder Geschichte der Danziger Nehrung, 1864. 


\section{Radostaw Kubus}

\section{ESCAPES FROM WISŁOUJŚCIE FORTRESS \\ IN THE FIRST HALF OF $19^{\mathrm{TH}}$ CENTURY}

The end of $18^{\text {th }}$ century Wisłoujście fortress was taken over by Prussia becoming 1 a prison where political and criminal prisoners were detained. Majority of captured. were Poles, for example members of "November uprising", as well as other nationalities. Based on wanted letters published in the official Gdańsk journal (Amtsblatt der Königlichen Regierung zu Danzig) the presentation shows escapes perpetrated by criminal prisoners, so-called "Baugefangene" as well as desertions of military entities quartering in Wisłoujście fortress and its nearby areas.

Keywords: escapes, desertions, Wisłoujście fortress, wanted letters, prisoners. 